\title{
Latitudinal influence on gametogenesis and host-parasite ecology in a marine bivalve model
}

\author{
Kate E. Mahony ${ }^{1,2,3}$ (1) | Sharon A. Lynch ${ }^{1,2,3}$ | Sian Egerton ${ }^{1,2,3}$ | Rebecca E. Laffan ${ }^{1,2,3}$ | \\ Simão Correia $^{4}$ | Xavier de Montaudouin ${ }^{5}$ | Nathalie Mesmer-Dudons ${ }^{5}$ | Rosa Freitas ${ }^{4}$ | \\ Sarah C. Culloty ${ }^{1,2,3}$
}

\author{
${ }^{1}$ School of Biological, Earth and \\ Environmental Sciences, University College \\ Cork, Cork, Ireland \\ ${ }^{2}$ Aquaculture and Fisheries Development \\ Centre, Environmental Research Institute, \\ University College Cork, Cork, Ireland \\ ${ }^{3}$ MaREI Centre for Climate, Energy and \\ Marine, Environmental Research Institute, \\ University College Cork, Cork, Ireland \\ ${ }^{4}$ Departamento de Biologia and CESAM, \\ Universidade de Aveiro, Aveiro, Portugal \\ ${ }^{5}$ UMR 5805 EPOC, CNRS, Université de \\ Bordeaux, Arcachon, France

\section{Correspondence} \\ Kate E. Mahony, School of Biological, Earth \\ and Environmental Sciences, University \\ College Cork, Cork, Ireland. \\ Email: kateellenmahony@gmail.com \\ Funding information \\ This work was funded by the COCKLES \\ project (EAPA_458/2016 COCKLES \\ Co-Operation for Restoring CocKle \\ SheLfisheries and its Ecosystem Services in \\ the Atlantic Area).
}

\begin{abstract}
Reproduction and parasites have significant impacts on marine animal populations globally. This study aimed to investigate the associative effects of host reproduction and a host-parasite interplay on a marine bivalve, along a geographic gradient of latitude. Cockles Cerastoderma edule were sampled from five European sites $\left(54^{\circ} \mathrm{N}\right.$ to $40^{\circ} \mathrm{N}$ ), between April 2018 and October 2019. A histological survey provided data on trematode (metacercaria and sporocyst life stages), prevalence, and cockle stage of gametogenesis to assess the influence of a latitudinal gradient on both interplays. Sex ratios at the northernmost sites were skewed toward females, and spawning size was reduced at the lower latitudes. Trematode infection did not follow a latitudinal gradient. Localized site-related drivers, namely seawater temperature, varied spatially, having an impact on cockle-trematode interactions. Spawning was related to elevated temperatures at all sites. Prolonged spawning occurred at southern latitudes, where seawater temperatures were warmer. Trematode prevalence and the impact of trematodes on gametogenesis were found to be spatially variable, but not latitudinally. Therefore, it is not possible to determine the likelihood of boom and bust events in cockles, based on the latitudinal location of a population. In terms of sublethal impacts, it appeared that energy was allocated to reproduction rather than somatic growth in southern populations, with less energy allocated to reproduction in the larger, northern cockles. The demonstrated spatial trend of energy allocation indicates the potential of a temporal trend of reduced cockle growth at northern sites, as a result of warming sea temperatures. This awareness of the spatially varying drivers of populations is crucial considering the potential for these drivers/inhibitors to be exacerbated in a changing marine environment.
\end{abstract}

\section{KEYWORDS}

boom and bust, cockles, fisheries, latitude, parasite-host interactions, reproduction, shellfish, spatial variation, trematodes

This is an open access article under the terms of the Creative Commons Attribution License, which permits use, distribution and reproduction in any medium, 


\section{1 | INTRODUCTION}

Boom and bust cycles with a pattern of population growth and decline are a commonly reported phenomenon, particularly in species exploited for fisheries and aquaculture (e.g., Hofmann \& Powell, 1998; Korman et al., 2017; You \& Hedgecock, 2019). These cycles are particularly evident in marine invertebrates (e.g., GamboaÁlvarez et al., 2020; Uthicke et al., 2009; van der Meer et al., 2001), which play vital roles ecologically. The common cockle (Cerastoderma edule, Cardiidae) is a suitable model organism due to its wide geographic range and well-studied biological characteristics (Malham et al., 2012), as well as ecological and commercial significance (Carss et al., 2020). The common cockle is found along Atlantic coasts, from Norway to West Africa (Allcock et al., 1995; Honkoop et al., 2008). This keystone species has previously been shown to experience some biogeographical variation in these cycles on a small scale (Morgan et al., 2013). However, escalations in boom and bust cycles are impacting cockles, with mortality events increasing as a result of factors such as climate change (e.g., extreme temperatures, increased precipitation, variability in water quality) and parasitism (Burdon et al., 2014). Therefore, examining the reproduction of cockles is vital for assessing populations, allowing for appropriate adjustments to be made to the minimum landing size and harvest quota, to provide protection for fisheries and ecosystems into the future.

In bivalves, including cockles, it is evident that many variables impact recruitment spatially and temporally influencing population dynamics and distribution (Beukema et al., 2001; Yankson, 1986). C. edule is a dioecious species that can undergo both epidemic and repetitive spawning (Cardoso et al., 2009). Cockles generally exhibit a 1:1 sex ratio (Boyden, 1971), with variations in age/length at first spawning (Cardoso et al., 2009; Elliott et al., 2012; Hancock \& Franklin, 1972). The typical reproductive cycle of cockles begins with gametogenesis in spring followed by spawning in the summer (Longshaw \& Malham, 2013). Variation is evident in this regime, with

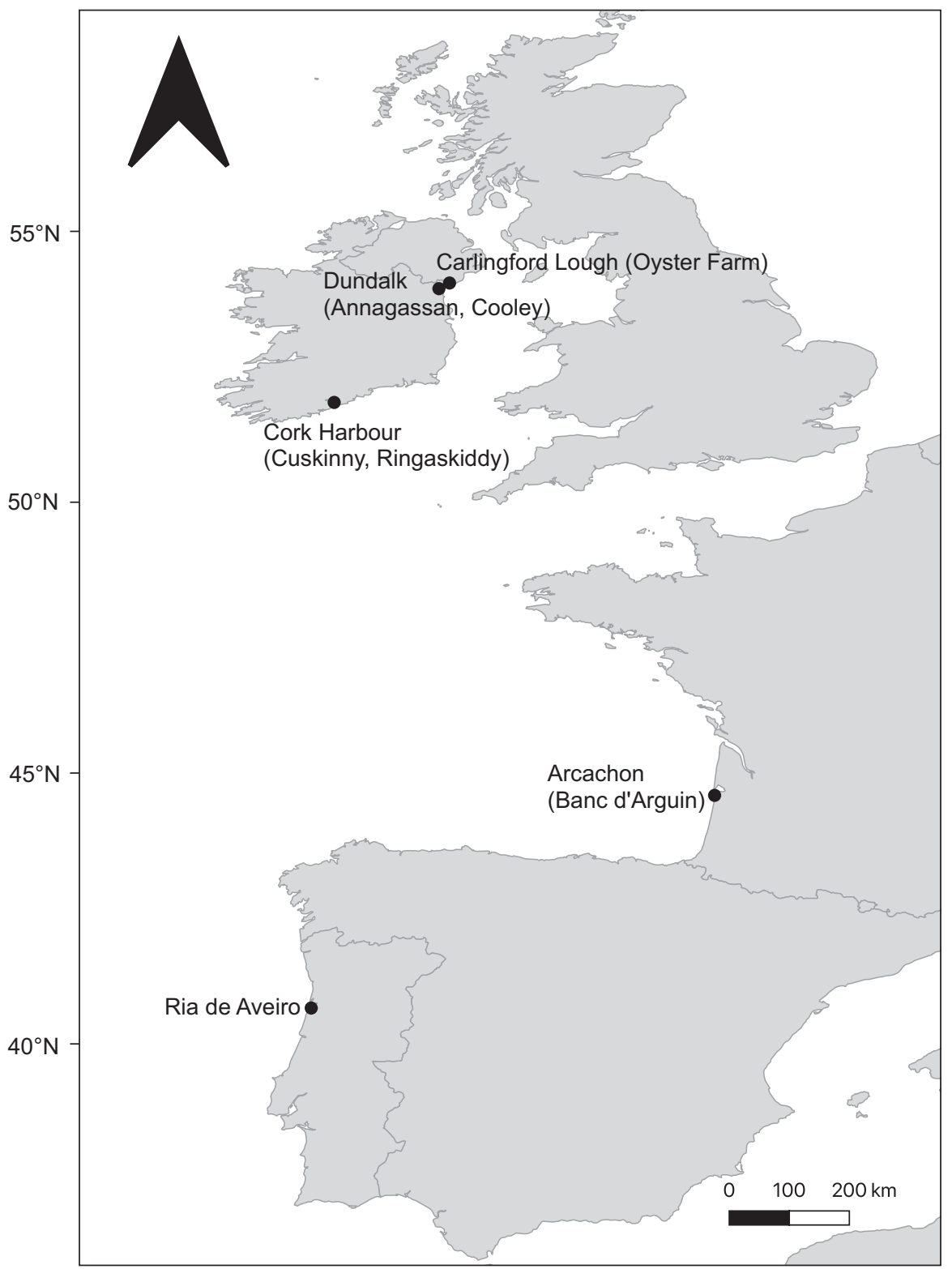

FIGURE 1 Geographical range of study sites in Ireland, France, and Portugal (bed names indicated in brackets) 
cockles in Trondheim, Norway $\left(63^{\circ} \mathrm{N}\right)$, spawning for a single month in summer (July) (Rygg, 1970) and cockles in the French Channel $\left(49^{\circ} \mathrm{N}\right)$ spawning throughout most of the year (Guillou et al., 1990). Previous multi-process studies on marine invertebrates have found mesoscale variation in reproduction (Lester et al., 2007). Furthermore, the timing of spawning and gametogenesis differs temporally even in cockles at the same geographic locations (Navarro et al., 1989). Many factors have been proposed as the drivers of spawning and gametogenesis in cockles, including temperature (Gam et al., 2010), water quality (Lusher et al., 2017), immersion time (Honkoop \& van der Meer, 1998), and feeding conditions in the previous season (Navarro et al., 1989). A particular cause for concern is the impact of changing climate on cockle reproduction (Morgan et al., 2013). In fact, it has already been shown that extreme events such as hot summers and cold winters negatively impact cockle recruitment and survival (Beukema \& Dekker, 2020).

Cockles also serve crucial ecological roles, such as acting as host to a large range of parasites (Longshaw \& Malham, 2013), with digenean trematodes being particularly dominant (Thieltges, 2006). As a group of parasites, they have a strong impact on tissue structure and morphology due to their size relative to the host. Trematodes exhibit a complex life cycle and cockles act as a primary (sporocysts) and/ or a secondary host (metacercariae) (de Montaudouin et al., 2009), which can have detrimental impacts on their health (de Montaudouin et al., 2012). For example, Bucephalus minimus (infecting as a first intermediate host) causes castration (Carballal et al., 2001) and starvation (Dubois et al., 2009). Gymnophallus choldochus (first and/ or second intermediate host) also causes castration in cockles by eliminating gonad structure (Thieltges, 2006). Parasites are a particularly essential factor to study in host dynamics, because climate change is likely to impact parasite-host interactions, which will not only impact the individual species, but the entire ecosystem due to trophic cascades (Marcogliese, 2008). Furthermore, the expanding northern range of some parasites (e.g., rhizocephalans) may cause local increases in transmission (Gehman et al., 2018) and increasing water temperature may result in trematode infections occurring year-round (de Montaudouin et al., 2016; Marcogliese, 2001). Such changes in parasite-host dynamics may prove disadvantageous to cockle populations.

The interplay between the reproductive and parasitic processes can have far-reaching impacts, associated with other spatially and temporally varying drivers. Energy allocation is a fine balance in bivalves, with energy needed for functions including somatic growth, reproduction, and immune response. This energy balance is intertwined with a range of external/environmental factors including temperature, latitude (Clarke, 1987), and parasitism (Lafferty \& Kuris, 2009). A common effect of parasites is castration, preventing the reproduction of a host of first intermediate hosts (Lafferty \& Kuris, 2009). However, it is difficult to differentiate this from the strategy of a host, diverting energy from reproduction in order to fight the parasite (Hurd, 2001). Host populations experiencing high rates of castration may exhibit altered life histories, with expedited maturity (Lafferty \& Kuris, 2009).

This 19-month study aimed to examine the influence of latitude, as well as the associative influence of trematode infection and sitespecific drivers (environmental and fishing type), on cockle reproductive health and population characteristics across a large proportion of its range. These findings will be vital for understanding this hostparasite system, particularly under the context of climate change.

\section{2 | MATERIALS AND METHODS}

\section{1 | Sample sites}

Five sites were included in the survey from the northernmost site, Carlingford Lough, to the southernmost, the Ria de Aveiro

TAB LE 1 Key details of the study sites examined for Cerastoderma edule, along with information on individual beds

\begin{tabular}{|c|c|c|c|c|c|}
\hline Site & Bed & Coordinates & $\begin{array}{l}\text { Seawater temperature } \\
\left({ }^{\circ} \mathrm{C}\right)\end{array}$ & Salinity & Abundance \\
\hline $\begin{array}{l}\text { Carlingford Lough } \\
\text { (Ireland) }\end{array}$ & Oyster Farm & $54^{\circ} 02^{\prime} \mathrm{N}, 6^{\circ} 10^{\prime} \mathrm{W}$ & $8.2-15^{a}$ & $19.8^{a}$ & - \\
\hline Dundalk Bay (Ireland) & $\begin{array}{l}\text { Annagassan } \\
\text { Cooley }\end{array}$ & $\begin{array}{l}53^{\circ} 52^{\prime} \mathrm{N}, 6^{\circ} 20^{\prime} \mathrm{W} \\
54^{\circ} 00^{\prime} \mathrm{N}, 6^{\circ} 17^{\prime} \mathrm{W}\end{array}$ & $6-17^{a}$ & $33.4-34^{a}$ & $\begin{array}{l}1,875 \text { tonnes in } \\
2018^{b}\end{array}$ \\
\hline Cork Harbour (Ireland) & $\begin{array}{l}\text { Cuskinny } \\
\text { Ringaskiddy }\end{array}$ & $\begin{array}{l}51^{\circ} 51^{\prime} \mathrm{N}, 8^{\circ} 15^{\prime} \mathrm{W} \\
51^{\circ} 49^{\prime} \mathrm{N}, 8^{\circ} 18^{\prime} \mathrm{W}\end{array}$ & $6.9-17.6^{a}$ & $33.1-34.8^{a}$ & $<10$ per $\mathrm{m}^{2}$ \\
\hline Arcachon Bay (France) & Banc d'Arguin & $44^{\circ} 35^{\prime} \mathrm{N}, 1^{\circ} 14^{\prime} \mathrm{W}$ & $9.5-21.1^{c}$ & $32-35^{c}$ & $\begin{array}{l}\text { Reaching } \\
2,390 \mathrm{ind} / \mathrm{m}^{\mathrm{c}}\end{array}$ \\
\hline $\begin{array}{l}\text { Ria de Aveiro } \\
\text { (Portugal) }\end{array}$ & Mira Channel & $40^{\circ} 38^{\prime} \mathrm{N}, 8^{\circ} 44^{\prime} \mathrm{W}$ & $11-22^{\mathrm{e}}$ & $0-36^{f}$ & $\begin{array}{l}\text { Reaching } \\
1,200 \mathrm{ind} / \mathrm{m}^{2}\end{array}$ \\
\hline
\end{tabular}

${ }^{\mathrm{a}}$ Copernicus (2020).

${ }^{\mathrm{b}}$ The Marine Institute and Bord lascaigh Mhara (2018).

'de Montaudouin and Lanceleur (2011).

${ }^{\mathrm{d}}$ Magalhães et al. (2016).

e $V a z$ et al. (2005).

fLillebø et al. (2015). 
TABLE 2 Descriptive statistics of all cockles examined in this study and number of males, females, and indeterminate $C$. edule from three Irish sites, one French site, and one Portuguese site

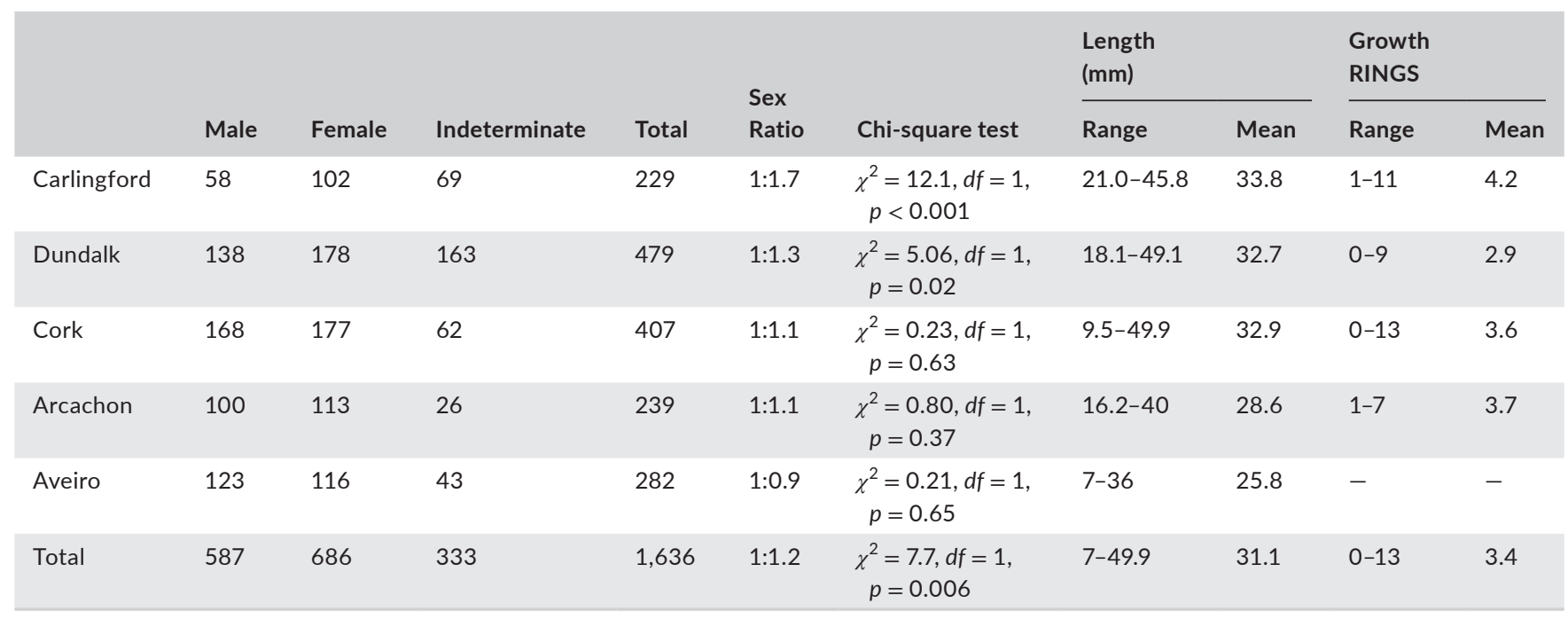

(Figure 1; Table 1). Only occasional hand harvesting occurs at Carlingford, but the area is important for mussel Mytilus spp. and Pacific oyster Crassostrea gigas aquaculture (Ferreira et al., 2007). The nearby Dundalk Bay supports a cockle fishery from July to October (Tully and Clarke, 2016). Cockle fishing does not occur at Cork Harbour. Cockle density at Arcachon Bay is very variable (de Montaudouin \& Lanceleur, 2011). Furthermore, since 2019, reported densities have been very low. Cockle densities at the Ria de Aveiro are also variable ( $<10$ to $\sim 1,200$ individuals per $\mathrm{m}^{2}$ ) due to year-round harvesting.

\section{2 | Sample collection}

The aim was to collect 30 samples from each bed every other month from April 2018 until October 2019 (19-month time period). Bimonthly sampling was deemed appropriate, following the slow development of cockles observed in the monthly sampling regime of Morgan et al. (2013). Some deviation occurred due to difficulties locating cockles or where cockle densities were low. At sample sites with rockier substrates (Carlingford and Cork), surfaced cockles were gathered by hand from the intertidal area. This method was deemed more appropriate and time effective with time constraints associated with tidal exchange. At the remaining sites, where sandy and muddy substrates were present, surfaced cockles were gathered by hand in combination with collection of buried cockles using a rake. In total, 1,636 cockles were examined using histology (Table 2). The total number of cockles examined via histology was less than the number collected in the field, due to occasional issues experienced during fixation related to tissue integrity.

Environmental data were derived from the Atlantic-Iberian Bay Irish-Ocean Physics Analysis and Forecast (Copernicus, 2020). Monthly sea surface temperature data $\left({ }^{\circ} \mathrm{C}\right)$ were derived from this dataset, from coordinates within the vicinity of the sample sites.
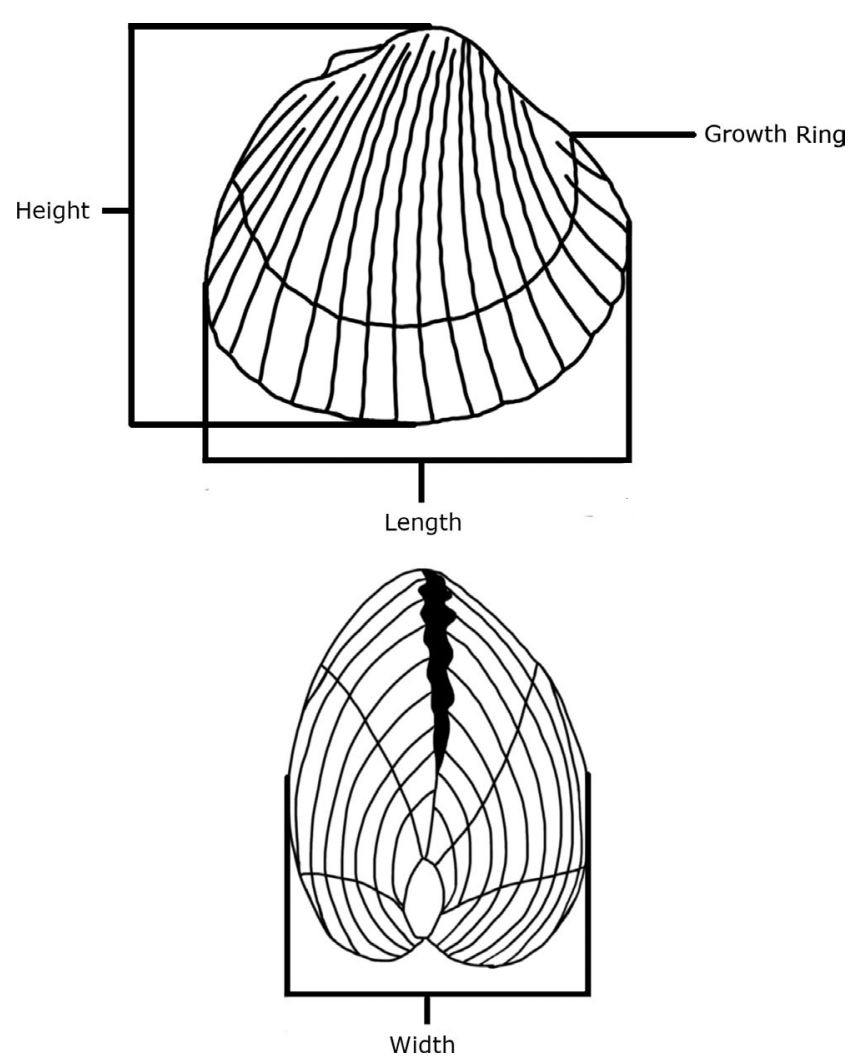

FIGURE 2 Measurements taken for cockle morphometrics to the nearest $\mathrm{mm}$

\section{3 | Cockle processing}

\subsection{1 | Morphometrics}

Prior to dissection and histology, the whole weight (shell and tissue) and shell morphometrics (Figure 2) were measured for each cockle. Growth rings in cockles are set down each winter (Orton, 1926), 
FIGURE 3 Proportion of Cerastoderma edule with and without evident gonad at each site. Months without a column indicate that sampling did not occur

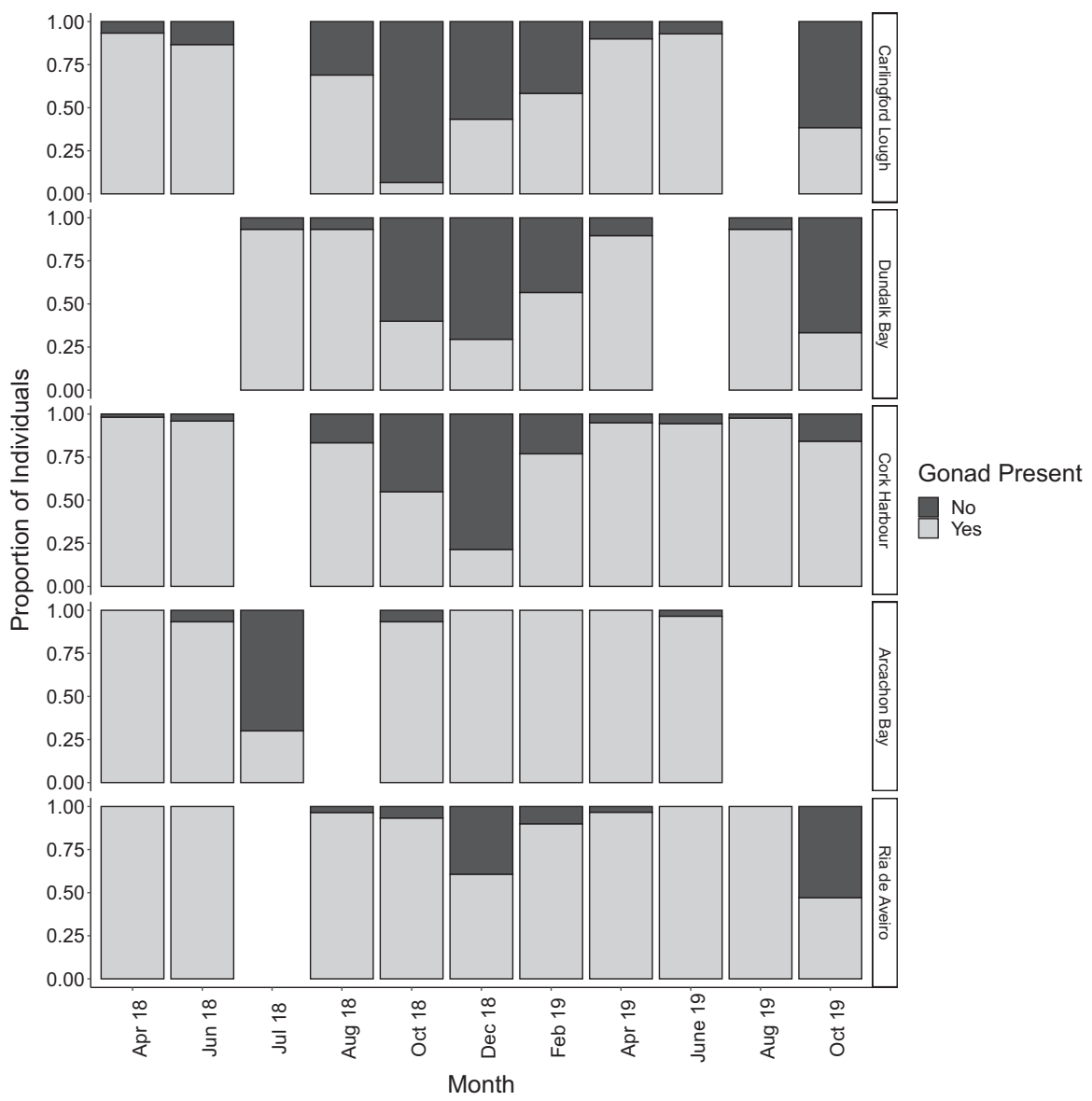

although sometimes lines may be hard to distinguish due to warm winters or short cold spells (Ponsero et al., 2009). Therefore, easily distinguishable growth rings were counted to determine an estimation of cockle age at all sites, with the exception of the Ria de Aveiro, where growth rings were not counted.

\subsection{2 | Histology}

The major cockle tissues (mantle, visceral mass, digestive system, foot, and gill) were removed from the shells and fixed in Bouin's solution (Arcachon samples) or Davidson's solution (all other samples) for 24-48 hr (Shaw \& Battle, 1957). Samples were then prepared for embedding in wax by running them through a 20-hr dehydration cycle of graded volumes of ethanol (adapted from Howard et al., 2004). The samples were sectioned to at least $5 \mu \mathrm{m}$ (3 $\mu \mathrm{m}$ if possible) before hematoxylin and eosin staining (Humason, 1979). Gonad staging was conducted according to the scale described by Morgan et al. (2013), where the gonad was classed according to six stages: early developing, late developing, ripe, spawning/partially spawning, and spent. When one individual exhibited multiple stages or an intermediate between two stages, the dominant stage was assigned. Cockles that did not have identifiable gonad were classed as indeterminate. Presence or absence of trematodes (either sporocysts or metacercaria stages) was also determined (Figure S1.1).
This was conducted using a NikonEclipse 80i light microscope, at $4 \times, 10 \times$, and $40 \times$.

\section{4 | Analysis}

The sexual cycle was described at each site and compared with the water temperature. All subsequent analyses were conducted in $R(R$ Core Team, 2019). A regression analysis was conducted to determine if there was a correlation between the percentage of individuals spawning and temperature. Pearson's chi-squared tests with Yate's continuity corrections were employed to examine the following questions:

1. Did sex ratio differ from 1:1 overall, and at each site/latitude?

2. Did the proportion of trematode infection vary across sites/ latitudes?

3. Did the percentage of individuals exhibiting each stage of gametogenesis vary according to trematode infection at the sites/ latitudes?

As appropriate, a post hoc analysis comparing the adjusted critical value with the adjusted residuals was conducted to determine which variables were significant at the $5 \%$ level. Finally, an analysis of covariance was employed to determine if seawater temperature was 
(a)

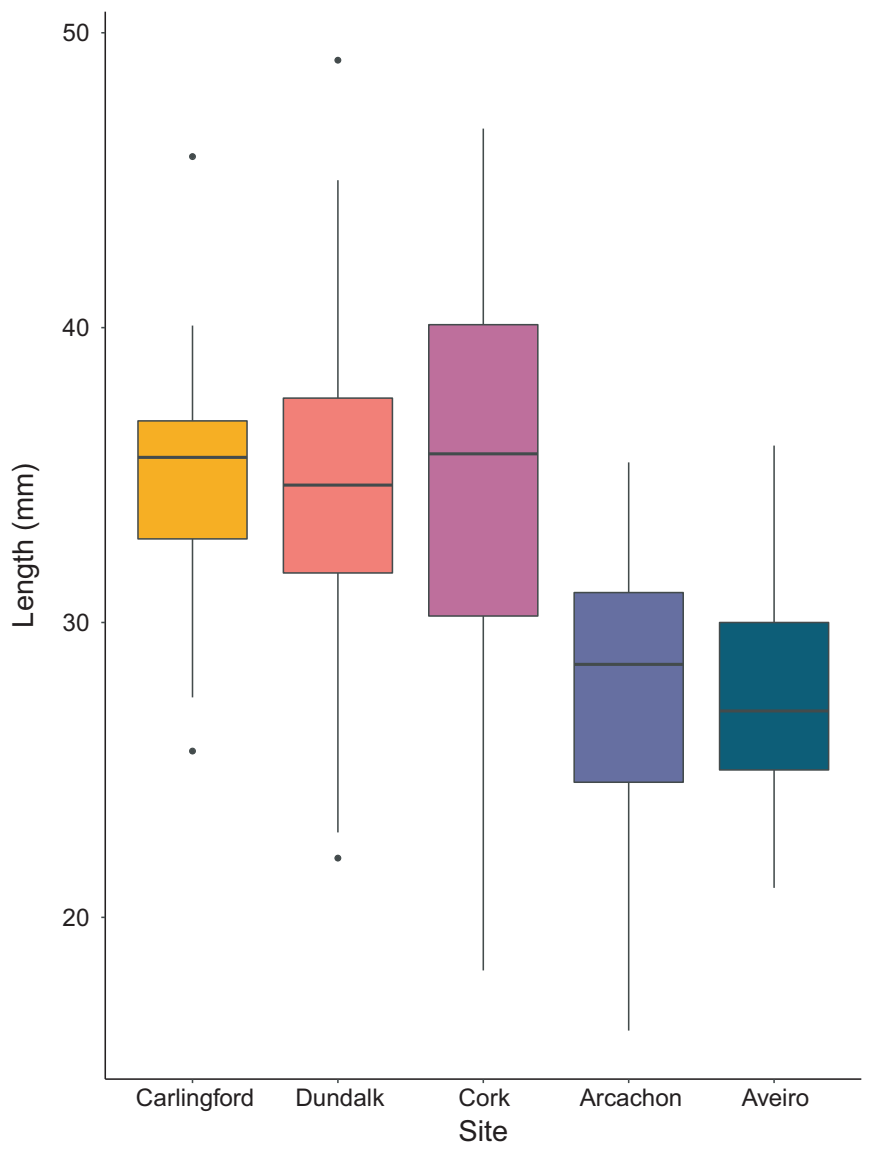

(b)

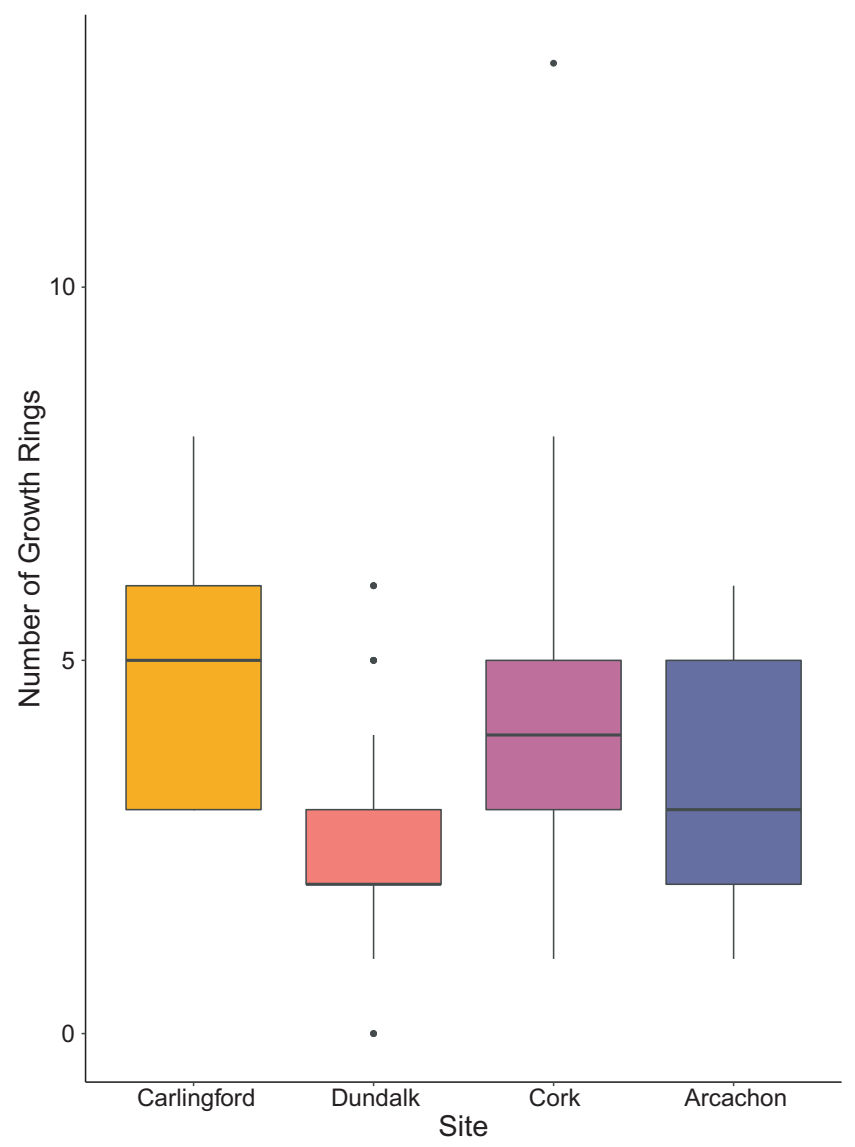

FIGURE 4 (a) Median (and interquartile range) of length at spawning for cockles at all sites and (b) median (and interquartile range) number of growth rings at spawning for cockles at all sites (excluding Ria de Aveiro)

associated with percentage of individuals spawning. Assumptions were evaluated using Levene's test for homogeneity of variance and the Shapiro-Wilk normality test.

Data were found to be nonparametric and were therefore submitted to Kruskal-Wallis tests followed by a Dunn test with a Bonferroni correction to examine pairwise differences in spawning length, spawning age, and proportion of indeterminate individuals between sites. Significance level was determined at the $95 \%$ probability level. Full statistical results are detailed in Appendix 1.

\section{3 | RESULTS}

\subsection{Spatial variation in seawater temperature}

Seawater temperatures did not follow a strict latitudinal gradient. Mean temperatures at Carlingford ranged from $8.2^{\circ} \mathrm{C}$ to $13.6^{\circ} \mathrm{C}$, with a mean of $11^{\circ} \mathrm{C}$. Despite the close proximity of Dundalk with Carlingford, water temperature ranged from $6.5^{\circ} \mathrm{C}$ to $17.4^{\circ} \mathrm{C}$, with a mean of $12.4^{\circ} \mathrm{C}$. Water temperature at Cork ranged from $8.5^{\circ} \mathrm{C}$ to $15.4^{\circ} \mathrm{C}$, with a mean of $12.2^{\circ} \mathrm{C}$. The mean water temperature at Arcachon Bay was the highest of all of the sites studied $\left(15.6^{\circ} \mathrm{C}\right)$ and ranged from $11.1^{\circ} \mathrm{C}$ to $21.5^{\circ} \mathrm{C}$. Despite being the southernmost site, water temperatures were lower at the Ria de Aveiro than in Arcachon Bay and had the narrowest range, from $12.6^{\circ} \mathrm{C}$ to $16.4^{\circ} \mathrm{C}$, with a mean of $14.8^{\circ} \mathrm{C}$.

\subsection{Relationship between sex ratio and indeterminate individuals with latitude}

Sex ratio only deviated from the expected 1:1 ratio at the two most northerly sites (Carlingford [1:1.7] and Dundalk [1:1.3]). Indeterminate individuals were found at all sites, with the percentage varying spatially $\left(\chi^{2}=13.7, d f=4, p=0.008\right)$. Higher percentages of indeterminate individuals were observed at Carlingford (the northernmost site), compared with the Ria de Aveiro ( $p=0.04$-trend) and Arcachon Bay $(p=0.02)$ (the southernmost sites). Proportions of indeterminate individuals appeared to vary over time, with expected peaks of indeterminate individuals observed during the winter months, while a resting period in gametogenesis occurred (Figure 3 ). However, the midlatitude site Arcachon Bay, in particular, had a shortened resting period during the summer after massive spawning when the majority of cockles were indeterminate. 


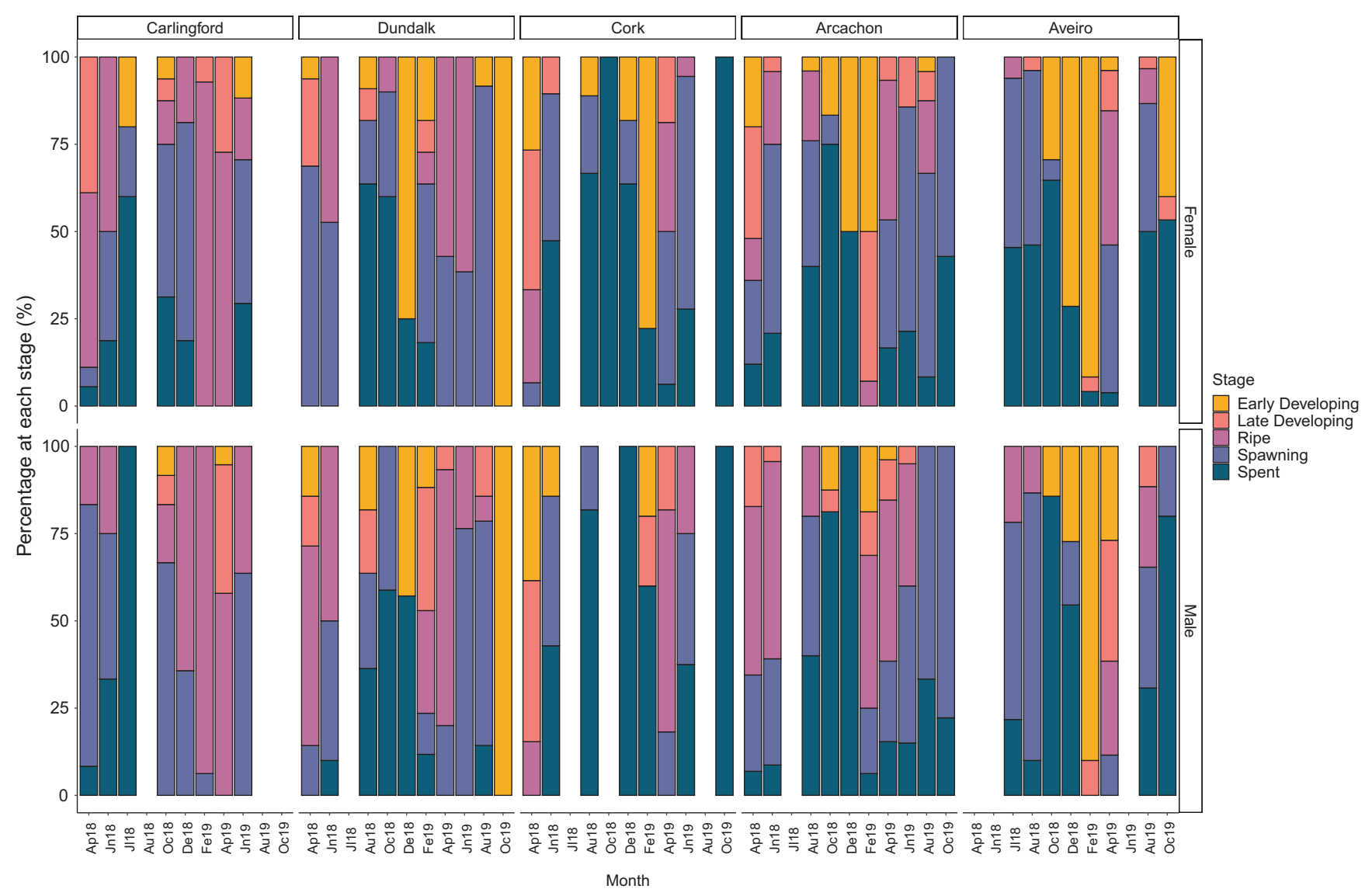

FIGURE 5 Percentage of $C$. edule at each stage of gonadal development at Irish, French, and Portuguese sites. Sampling commenced in April 2018 (Ap18) and was completed in October 2019 (Oc19). Indeterminate individuals were omitted and included in Figure 3. Months with no bar indicate that sampling was not conducted

\section{3 | Relationship between cockle size, age, and spawning}

Cockles spawning at the more southern sites of Arcachon Bay and the Ria de Aveiro were significantly smaller than all of the other sites ( $p<0.001$ in all cases, Figure 4a). However, age did not follow the same gradient, with large variations of spawning age within the Irish sites (Figure 4b).

\subsection{Sexual cycle and seawater temperature}

Spawning duration and frequency varied between Irish sites, between countries and inter-annually. At Carlingford, a single spawning period (April-October) was observed in both years. In 2018, spawning at Dundalk continued until August in females and October in males, with development recommencing by October 2018 in both sexes. A second, smaller spawning in 2018 was observed in males (20\%) in December but did not continue throughout the winter (Figure 5). At Cork, a single spawning event was noted in 2018 , ceasing during the winter, indicated by an absence of spent males in February 2019 (Figure 5). However, spawning individuals were observed during all months when sampling took place during 2019. At the southern sites (Arcachon Bay and the Ria de Aveiro), resting periods appeared shorter (Figure 5), with spawning observed during the majority of sampled months (and likely during the interim months due to the numbers of spent individuals observed).

At the northernmost sites, a synergy between temperature and spawning time was evident (Figure 6). A positive correlation between percentage of individuals spawning and temperature was observed at Dundalk ( $p=0.002, F=14.2, d f=1$ ), and at Cork, there was a similar trend ( $p=0.061, F=3.994, d f=1)$. No significant correlation was observed at the other sites, but there appeared to be an overall positive trend between increased spawning and increasing temperature (Figure 6).

Differences in the male-female synchronicity of gametogenesis were observed between sites. At Carlingford, spawning generally appeared synchronous between sexes, although more females were spawning in 2019 (Figure 6). At Cork, one of the other northern sites, it appeared that more females were spawning in 2018, with the converse occurring in 2019. At Arcachon Bay, more males were spawning in early 2018 (Figure 6) and at the southernmost site, the Ria de Aveiro, spawning of both sexes was less synchronous in 2018 than in 2019, where similar numbers were spawning in both sexes by June (Figure 6). Spawning at the Ria de Aveiro appeared to be initiated by females in both years (Figure 6). 


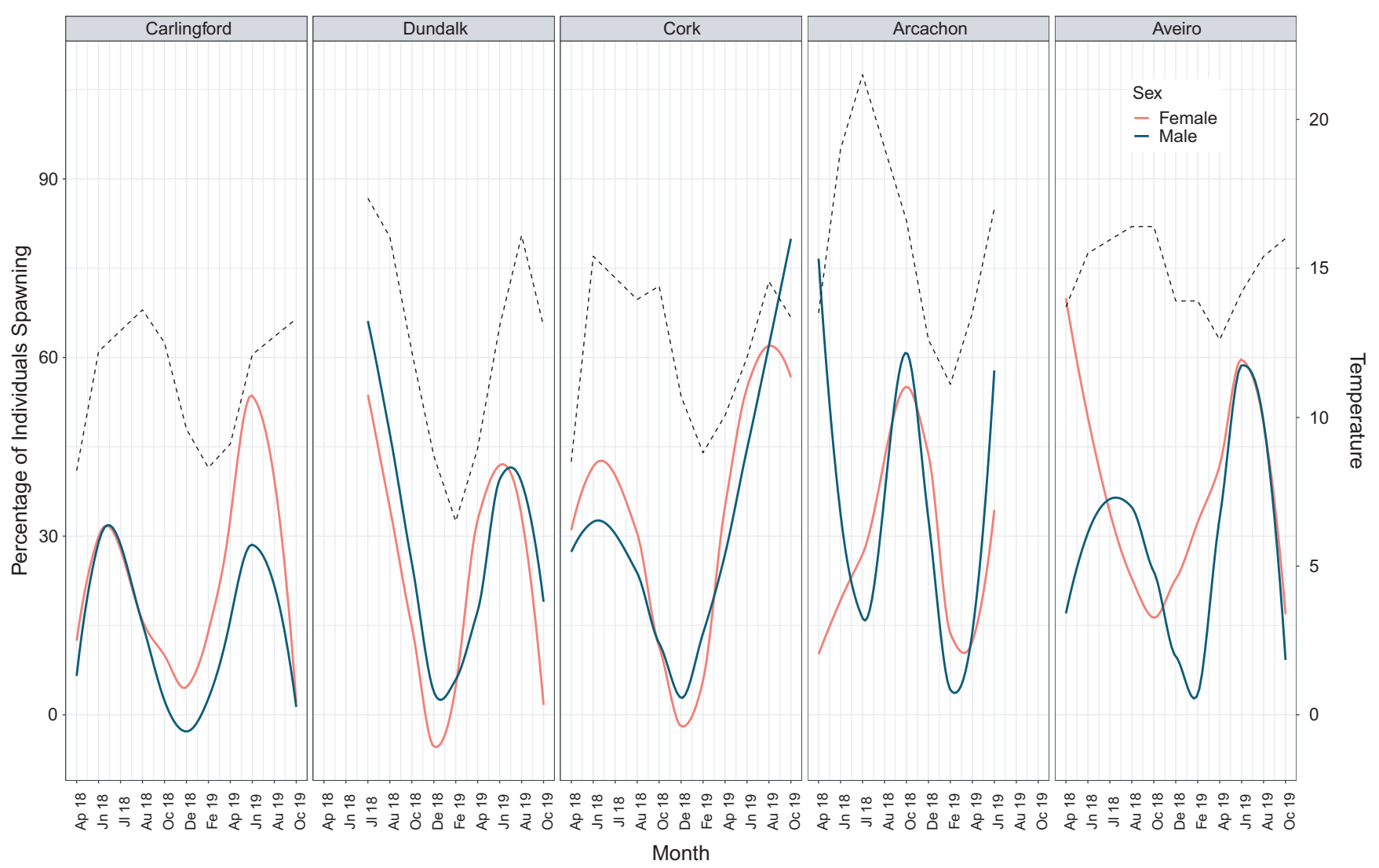

FIGURE 6 Percentage of males (blue line) and females (red line) spawning during each month of the study, compared with sea water temperature (dotted line), at each site

\section{5 | Patterns of trematode infection and impact on cockle gametogenesis (reproductive cycle)}

Trematode infection varied spatially, with both sporocysts and metacercariae present at all sites but not along a latitudinal gradient. Sporocyst prevalence was highest at Arcachon Bay (12.1\%), and metacercariae prevalence was highest at Carlingford (81.7\%). However, prevalence of both stages was lowest at the southernmost site (the Ria de Aveiro: sporocysts $=2.1 \%$, metacercariae $=9.6 \%$ ). Prevalence of infection by metacercariae generally increased with higher water temperature, peaking between $\sim 13.5^{\circ} \mathrm{C}$ and $17.5^{\circ} \mathrm{C}$ (Figure 7). However, Arcachon Bay was the exception; therefore, a latitudinal gradient was not obvious, with metacercarial prevalence at Arcachon Bay decreasing gradually over the summer months, when the temperature reached a monthly mean of $22.2^{\circ} \mathrm{C}$ in July 2019 , exceeding that of all other sites, peaking in December at $60 \%$ infection (mean temperature at Arcachon $=12.6^{\circ} \mathrm{C}$ ) (Figure 7).

Overall, a trend was observed where metacercariae infected individuals were more likely to be indeterminate than to be ripe or spawning ( $p=0.08$, in both cases). Similarly, coinfected individuals were more likely to be indeterminate, rather than ripe or spawning ( $p=.008$, in both cases, Figure 8). No significant relationship was observed between cockles solely infected with sporocysts and stage of gametogenesis.

\section{4 | DISCUSSION}

This study highlighted the biogeographical differences in cockle populations, showing that there is an associative influence of trematode infection, temperature, and latitude on population dynamics and reproduction development. Increased water temperatures influenced trematode prevalence, until a threshold temperature was reached $\left(20^{\circ} \mathrm{C}\right)$, when prevalence decreased, potentially impacting cockles at more southern, warmer locations. Trematodes had a deleterious effect on cockle reproduction, with a reduced proportion of spawning individuals and higher numbers of indeterminate individuals among those infected, regardless of latitude or other local factors. While latitude did not have evident impact on the parasitism aspect of the boom and bust cycle, cockle energy allocation and gametogenesis patterns followed a latitudinal gradient, that is, the northernmost sites exhibiting spawning peaks at similar times in the year. Furthermore, spawning occurred almost year-round at the two southernmost sites, despite variations in average seawater temperature between them. It is also important to note that while bimonthly sampling sufficed at the Irish sites and the Ria de Aveiro (cooler sites), more frequent sampling may be necessary at Arcachon (and possibly other warmer sites), to examine the more accelerated gametogenesis here.

A potential link between sex ratio and latitude was found, with the northernmost latitudes both experiencing skewed sex ratios, despite 

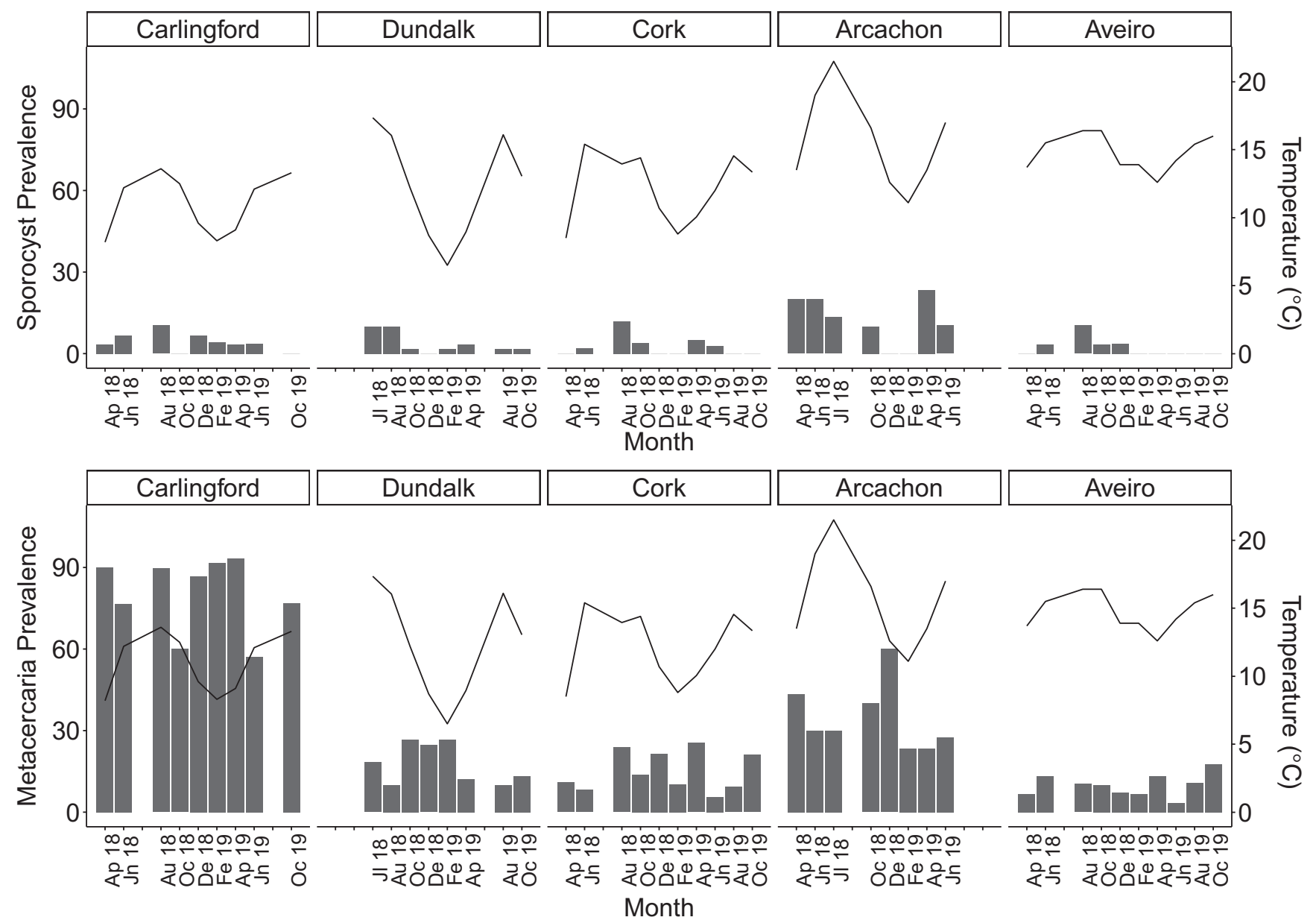

FIGURE 7 Time series of trematode prevalence (metacercariae and sporocysts) recorded in C. edule at all study sites, compared with seawater temperature (solid line). Individuals coinfected with metacercariae and sporocysts were included in both graphs. Months without a label indicate that sampling did not occur

both varying in terms of fishing pressure and trematode infection. Significantly higher numbers of females were found at these northerly, nearby sites of Carlingford and Dundalk, a phenomenon also seen in other cockle populations (Boyden, 1970; Martínez-Castro \& Vázquez, 2012). A number of explanations may be suggested. First, deviation from a 1:1 sex ratio can result from sex-specific mortality (Longshaw \& Malham, 2013) and it is possible that trematode infection was higher in males, as suggested by a previous study (Morgan et al., 2012). However, further research would be required to test this hypothesis, considering the many species of parasites found in cockles (de Montaudouin et al., 2009; Longshaw \& Malham, 2013). Another possibility is that a genetic element of sex determination is at play, with large genetic diversity recorded spatially in cockles previously (Martínez et al., 2015). However, further studies would be required to determine this.

Significant site differences were found in the age and size of spawning cockles. Latitude appeared to be an influencing factor, but fishing activity may also have a role. Older and larger spawning cockles were found at Cork as might be expected as the site is free of any cockle fishing activity. Cockles at Carlingford, a site also free of large-scale commercial fishing, reached similar ages to Cork cockles.
The heavily fished sites had smaller and younger spawning cockles than unfished sites. At the southern sites (the Ria de Aveiro and Arcachon Bay), this may be because cockles allocate more energy toward longer spawning periods, rather than somatic growth. Such variations in reproductive and life history strategies, through differing energy allocation, have been found in other shellfish (Egerton et al., 2020). However, it is also possible that temperature, food availability, and water quality are impacting growth and maturity in cockles (Gosling, 2015); it would be beneficial to further investigate these drivers.

Although seawater temperature, and a range of other local factors, influenced trematode prevalence, it did not follow a latitudinal gradient. Trematode infection levels varied across sites, with the highest prevalence detected at Carlingford. However, it is important to consider that histological methods, such as those used in this study, may result in an underestimation of trematode prevalence, as not all tissue is screened (Morgan et al., 2012). Similar to previous observations (de Montaudouin et al., 2000), at Carlingford there was a high metacercariae prevalence, as well as a high abundance of old cockles. However, metacercariae intensity was not examined and may in fact have been low due to the 


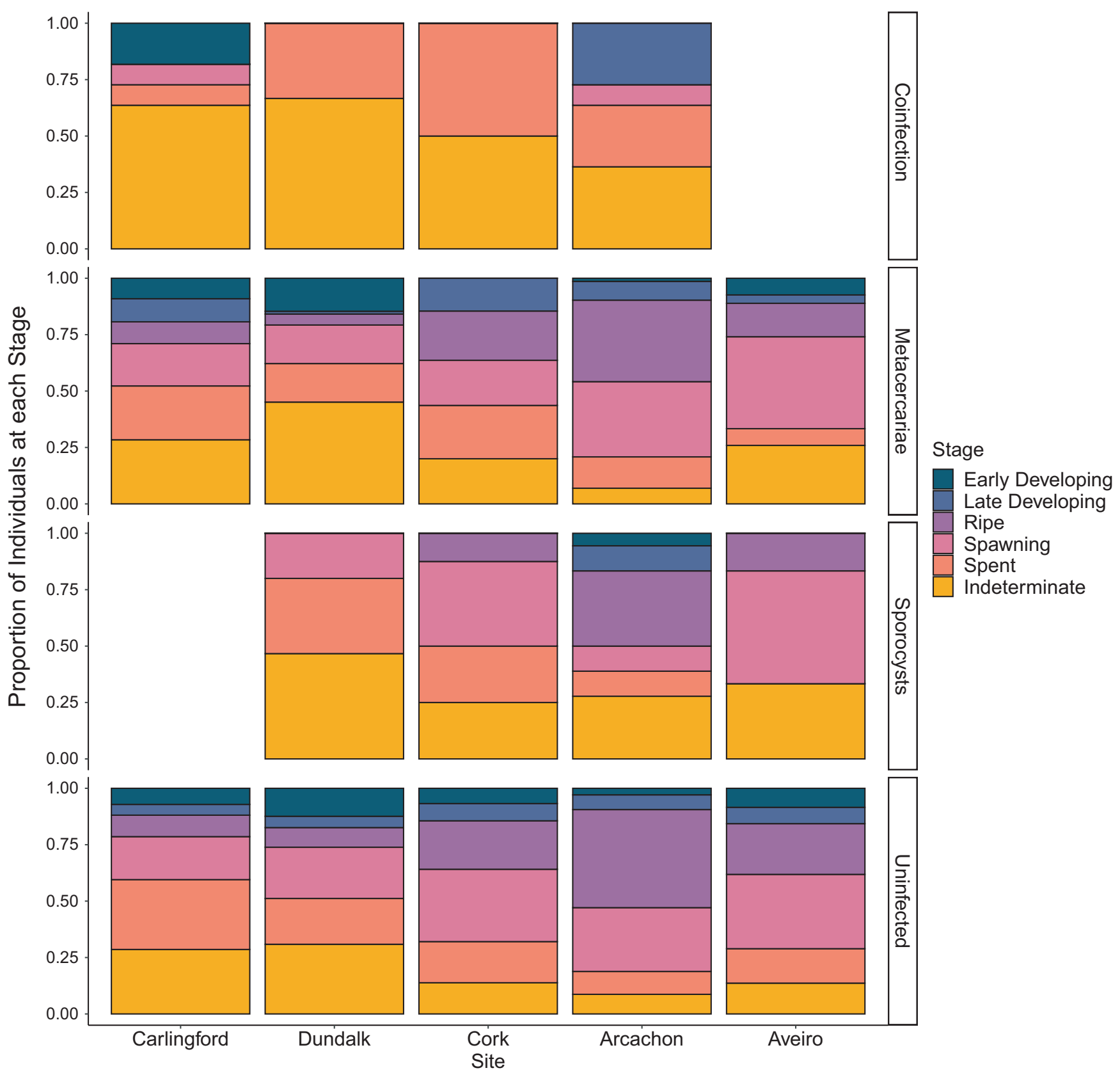

FIGURE 8 Proportion of $C$. edule at each stage of gametogenesis for individuals infected and uninfected by sporocysts and metacercariae. "Coinfection" indicates that an individual was coinfected by sporocysts and metacercariae

dilution effect of sympatric Cr. gigas (Krakau et al., 2006). Another driver of differences in these sites may be the presence of intermediate and final host species (Byers et al., 2008; de Montaudouin \& Lanceleur, 2011; Hechinger \& Lafferty, 2005; Thieltges \& Reise, 2006, 2007). At Carlingford, birds may not be the factor driving prevalence, due to high human activity on the oyster farm, but it would be worth examining abundance and trematode infection in gastropod species here (Longshaw \& Malham, 2013). Interestingly, high numbers of barnacles were observed fouling cockles at Carlingford (Personal Observation). These fouling organisms potentially keep cockle shells from closing entirely, thus increasing the potential for trematode infection, but conversely can predate cercariae (Welsh et al., 2017). Cockle density also differed greatly between Cork and Carlingford, the two sites with low fishing impact. Notably, a lower density of cockles in Cork coincided with lower trematode prevalence. However, it is difficult to ascertain the relationship between host density and trematode prevalence (Magalhães et al., 2017). For example, Cork and the Ria de Aveiro, sites with a large density difference, both reported low trematode prevalence. It may be that these factors are acting additively or synergistically, explaining the differences between sites.

Cockles may go through an over-wintering stage when their gonad is undifferentiated (Boyden, 1970), and unsurprisingly, high levels of indeterminate individuals were found at all sites, mostly 
from autumn to winter. However, indeterminate individuals were observed year-round in the northern sites (Carlingford, Dundalk, and Cork). Many trematode species cause castration (Carballal et al., 2001; Thieltges, 2006), and in this study, a higher proportion of infected cockles were of indeterminate sex, compared to at a ripe or spawning stage. It is generally believed that parasites infecting as sporocysts (reproductive stage) are likely to cause more damage than those infecting as metacercariae (encystment stage) (Wegeberg \& Jensen, 1999). However, it was evident that both metacercariae and sporocysts have a deleterious effect on reproduction, with reduced spawning and higher numbers of indeterminate individuals in trematode infected cockle communities.

Findings from this study indicate the geographical variation impacting cockle reproduction, with temperature, trematode infection, and gametogenesis acting associatively. Spawning appeared to be prolonged at the southern sites (the Ria de Aveiro and Arcachon Bay), potentially causing a re-allocation of energy resources away from individual growth, denoting varying life history strategies among different genetic groups, and sites. Trematode prevalence was related to sea water temperature, while gametogenesis and spawning are impacted by trematodes and water temperature, as shown in this study, as well as by a range of biotic and abiotic factors influencing energy reserves and cockle production (Rueda et al., 2005). The latitudinally varying sizes indicate a link with temporal changes resulting from climate change, with the potential for significant changes in cockle reproduction and host-parasite ecology related to warming seas. These findings are not limited to cockles (Lester et al., 2007), and many of the factors impacting commercially exploited marine species at both a local and regional scale are likely to change as a result of a changing environment, thus highlighting the importance of regular monitoring to follow shifting population dynamics.

\section{ACKNOWLEDGMENTS}

This work was funded by the COCKLES project (EAPA_458/2016 COCKLES Co-Operation for Restoring CocKle SheLfisheries and its Ecosystem Services in the Atlantic Area). The authors would like to thank Kian Louet-Feisser and Brian McGill of Carlingford Oyster Company, and Martin Hoey for field work advise and collection of cockles. Thanks are also due to Sara Albuixech Martí and Katie Costello for their assistance in field work and the preparation of samples. Sampling in Banc d'Arguin, France, was possible thanks to the availability of the vessel Planula IV (Flotte Océanographique Française, CNRS-INSU) and the help of SEPANSO (National reserve manager).

\section{CONFLICTS OF INTEREST}

None declared.

\section{AUTHOR CONTRIBUTIONS}

Kate E. Mahony: Data curation (lead); formal analysis (lead); investigation (lead); writing - original draft (lead); writing - review and editing (lead). Sharon A. Lynch: Conceptualization (equal); methodology (equal); project administration (equal); supervision (equal); writing - review and editing (equal). Sian Egerton: Project administration (equal); writing - review and editing (equal). Rebecca E. Laffan: Data curation (equal); writing - review and editing (equal). Simão Correia: Data curation (equal); investigation (equal); writing review and editing (equal). Xavier de Montaudouin: Data curation (equal); methodology (equal); writing - review and editing (equal). Nathalie Mesmer-Dudons: Data curation (equal); writing - review and editing (equal). Rosa Freitas: Data curation (equal); writing review and editing (equal). Sarah C. Culloty: Conceptualization (equal); funding acquisition (equal); methodology (equal); project administration (equal); supervision (equal); writing - review and editing (equal).

\section{DATA AVAILABILITY STATEMENT}

Data used in this study is available in the Dryad Digital Depository https://doi.org/10.5061/dryad.s1rn8pk7b

\section{ORCID}

Kate E. Mahony (iD https://orcid.org/0000-0001-8017-2483

\section{REFERENCES}

Allcock, L. A., Hayward, P. J., Wigham, G. D., \& Yonow, N (1995). In P. J. Hayward, \& J. S. Ryland (Eds.), Molluscs (Phylum Mollusca). Handbook of the marine fauna of North-West Europe (pp. 455-602). Oxford University Press.

Beukema, J. J., \& Dekker, R. (2020). Winters not too cold, summers not too warm: Long-term effects of climate change on the dynamics of a dominant species in the Wadden Sea: The cockle Cerastoderma edule L. Marine Biology, 167, 44. https://doi.org/10.1007/s0022 7-020-3659-1

Beukema, J. J., Dekker, R., Essink, K., \& Michaelis, H. (2001). Synchronized reproductive success of the main bivalve species in the Wadden Sea: Causes and consequences. Marine Ecology Progress Series, 211, 143-155.

Boyden, C. R. (1970). Comparative studies on Cerastoderma edule (L.) and Cerastoderma glaucum (Poiret). London: Queen Mary College.

Boyden, C. R. (1971). A note on the nomenclature of two European cockles. Zoological Journal of the Linnean Society, 50, 307-310. https://doi. org/10.1111/j.1096-3642.1971.tb00765.x

Burdon, D., Callaway, R., Elliott, M., Smith, T., \& Wither, A. (2014). Mass mortalities in bivalve populations: A review of the edible cockle Cerastoderma edule (L.). Estuarine, Coastal and Shelf Science, 150, 271280. https://doi.org/10.1016/j.ecss.2014.04.011

Byers, J. E., Blakeslee, A. M. H., Linder, E., Cooper, A. B., \& Maguire, T. J. (2008). Controls of spatial variation in the prevalence of trematode parasites infecting a marine snail. Ecology, 89(2), 439-451. https:// doi.org/10.1890/06-1036.1

Carballal, M. J., Iglesias, D., Santamarina, J., Ferro-Soto, B., \& Villalba, A. (2001). Parasites and pathologic conditions of the cockle Cerastoderma edule populations of the Coast of Galicia (NW Spain). Journal of Invertebrate Pathology, 78, 87-97. https://doi.org/10.1006/ jipa.2001.5049

Cardoso, J. F. M. F., Witte, J., \& van der Veer, H. W. (2009). Differential reproductive strategies of two bivalves in the Dutch Wadden Sea. Estuarine, Coastal and Shelf Science, 84, 37-44. https://doi. org/10.1016/j.ecss.2009.05.026

Carss, D. N., Brito, A. C., Chainho, P., Ciutat, A., de Montaudouin, X., Fernández Otero, R. M., Filgueira, M. I., Garbutt, A., Goedknegt, M. A., Lynch, S. A., Mahony, K. E., Maire, O., Malham, S. K., Orvain, F., van der Schatte Olivier, A., \& Jones, L. (2020). Ecosystem services 
provided by a non-cultured shellfish species: The common cockle Cerastoderma edule. Marine Environmental Research, 158, 104931. https://doi.org/10.1016/j.marenvres.2020.104931

Clarke, A. (1987). Temperature, latitude and reproductive effort. Marine Ecology Progress Series, 38, 89-99. https://doi.org/10.3354/meps0 38089

Copernicus. (2020). Global ocean $1 / 12^{\circ}$ physics analysis and forecast updated daily. Retrieved from https://resources.marine.copernicus. eu/documents/PUM/CMEMS-GLO-PUM-001-024.pdf. Accessed December 7, 2020

de Montaudouin, X., Bazairi, H., \& Culloty, S. (2012). Effect of trematode parasites on cockle Cerastoderma edule growth and condition index: A transplant experiment. Marine Ecology Progress Series, 471, $111-$ 121. https://doi.org/10.3354/meps10033

de Montaudouin, X., Blanchet, H., Desclaux-Marchand, C., Lavesque, N., \& Bachelet, G. (2016). Cockle infection by Himasthla quissetensis - I. From cercariae emergence to metacercariae infection. Journal of Sea Research, 113, 99-107. https://doi.org/10.1016/j.seares.2015.02.008

de Montaudouin, X., Kisielewski, I., Bachelet, G., \& Desclaux, C. (2000). A census of macroparasites in an intertidal bivalve community, Arcachon Bay. France. Oceanologica Acta, 23(4), 453-468. https:// doi.org/10.1016/S0399-1784(00)00138-9

de Montaudouin, X., \& Lanceleur, L. (2011). Distribution of parasites in their second intermediate host, the cockle Cerastoderma edule: Community heterogeneity and spatial scale. Marine Ecology Progress Series, 428, 187-199. https://doi.org/10.3354/meps09072

de Montaudouin, X., Thieltges, D. W., Gam, M., Krakau, M., Pina, S., Bazairi, H., Dabouineau, L., Russell-Pinto, F., \& Jensen, K. T.. (2009). Digenean trematode species in the cockle Cerastoderma edule: Identification key and distribution along the North-Eastern Atlantic Shoreline. Journal of the Marine Biological Association of the United Kingdom, 89(3), 543-556.

Dubois, S. Y., Savoye, N., Sauriau, P.-G., Billy, I., Martinez, P., \& de Montaudouin, X. (2009). Digenean trematodes-marine mollusc relationships: A stable isotope study. Diseases of Aquatic Organisms, 84, 65-77. https://doi.org/10.3354/dao02022

Egerton, S., Lynch, S. A., Prado-Alvarez, M., Flannery, G., Brennan, E., Hugh-Jones, T., Hugh-Jones, D., \& Culloty, S. C. (2020). A naïve population of European oyster Ostrea edulis with reduced susceptibility to the pathogen Bonamia ostreae: Are S-strategy life traits providing protection? Integrative and Comparative Biology, 60(2), 249-260. https://doi.org/10.1093/icb/icaa071

Elliott, M., Burdon, D., Callaway, R., Franco, A., Hutchinson, T., Longshaw, M., \& Wither, A. (2012). Burry Inlet cockle mortalities investigation 2009-2011. Hull: Institute of Estuarine \& Coastal Studies.

Ferreira, J. G., Hawkins, A. J. S., \& Bricker, S. B. (2007). Management of productivity, environmental effects and profitability of shellfish aquaculture - the Farm Aquaculture Resource Management (FARM) model. Aquaculture, 264, 160-174. https://doi.org/10.1016/j.aquac ulture.2006.12.017

Gam, M., de Montaudouin, X., \& Bazairi, H. (2010). Population dynamics and secondary production of the cockle Cerastoderma edule: A comparison between Merja Zerga (Moroccan Atlantic Coast) and Arcachon Bay (French Atlantic Coast). Journal of Sea Research, 63, 191-201. https://doi.org/10.1016/j.seares.2010.01.003

Gamboa-Álvarez, M. Á., López-Rocha, J. A., Poot-López, G. R., AguilarPerera, A., \& Villegas-Hernández, H. (2020). Rise and decline of the sea cucumber fishery in Campeche Bank. Mexico, Ocean and Coastal Management, 184, 105011. https://doi.org/10.1016/j.oceco aman.2019.105011

Gehman, A.-L.-M., Hall, R. J., \& Byers, J. E. (2018). Host and parasite thermal ecology jointly determine the effect of climate warming on epidemic dynamics. Proceedings of the National Academy of Sciences, 115(4), 744-749. https://doi.org/10.1073/pnas.1705067115
Gosling, E. (2015). Marine bivalve molluscs, 2nd ed. Chichester, West Sussex, UK: Wiley Blackwell.

Guillou, J., Bachelet, G., Desprez, M., Ducrotoy, J.-P., Madani, I., Rybarczyk, H., \& Glemaree, M. (1990). Events in the reproduction of Cerastoderma edule L. along the French Channel and Atlantic coasts. Aquatic Living Resources, 3, 29-41.

Hancock, D. A., \& Franklin, A. (1972). Seasonal changes in the condition of the edible cockle (Cardium edule L.). Journal of Applied Ecology, 9(2), 567-579. https://doi.org/10.2307/2402454

Hechinger, R. F., \& Lafferty, K. D. (2005). Host diversity begets parasite diversity: Bird final hosts and trematodes in snail intermediate hosts. Proceedings of the Royal Society B: Biological Sciences, 272, 1059-1066.

Hofmann, E. E., \& Powell, T. M. (1998). Environmental variability effects on marine fisheries: Four case histories. Ecological Applications, 8(1), S23-S32. https://doi.org/10.2307/2641360

Honkoop, P. J. C., Berghuis, E. M., Holthuijsen, S., Lavaleye, M. S., \& Piersma, T. (2008). Molluscan assemblages of seagrass-covered and bare intertidal flats on the Banc d'Arguin, Mauritania, in relation to characteristics of sediment and organic matter. Journal of Sea Research, 60, 255-263. https://doi.org/10.1016/j.seares.2008.07.005

Honkoop, P. J. C., \& van der Meer, J. (1998). Experimentally induced effects of water temperature and immersion time on reproductive output of bivalves in the Wadden Sea. Journal of Experimental Marine Biology and Ecology, 220, 227-246. https://doi.org/10.1016/S0022 -0981(97)00107-X

Howard, D. W., Lewis, E. J., Keller, B. J., \& Smith, C. S. (2004). Histological techniques for marine bivalve mollusks and crustaceans. 2nd ed. NOAA Technical Memorandum NOS NCCOS 5. Oxford MD: NOAA.

Humason, G. (1979). Animal tissue techniques, 4th ed. Freeman and Co.

Hurd, H. (2001). Host fecundity reduction: A strategy for damage limitation? Trends in Parasitology, 17(8), 363-368. https://doi.org/10.1016/ S1471-4922(01)01927-4

Korman, J., Yard, M. D., \& Kennedy, T. A. (2017). Trends in rainbow trout recruitment, abundance, survival, and growth during a boomand-bust cycle in a tailwater fishery. Transactions of the American Fisheries Society, 146, 1043-1057. https://doi.org/10.1080/00028 487.2017.1317663

Krakau, M., Thieltges, D. W., \& Reise, K. (2006). Native parasites adopt introduced bivalves of the North Sea. Biological Invasions, 8, 919925. https://doi.org/10.1007/s10530-005-4734-8

Lafferty, K. D., \& Kuris, A. M. (2009). Parasitic castration: The evolution and ecology of body snatchers. Trends in Parasitology, 25(12), 564572. https://doi.org/10.1016/j.pt.2009.09.003

Lester, S. E., Gaines, S. D., \& Kinlan, B. P. (2007). Reproduction on the edge: Large-scale patterns of individual performance in a marine invertebrate. Ecology, 88(9), 2229-2239. https://doi. org/10.1890/06-1784.1

Lillebø, A. I., Stålnacke, P., \& Gooch, G. D. (2015). Coastal lagoons in Europe. Integrated water resource strategies. IWA Publishing.

Longshaw, M., \& Malham, S. K. (2013). A review of the infectious agents, parasites, pathogens and commensals of European cockles (Cerastoderma edule and C. glaucum). Journal of the Marine Biological Association of the United Kingdom, 93(1), 227-247.

Lusher, A. L., Pope, N., \& Handy, R. D. (2017). Reproductive effects of endocrine disrupting chemicals, bisphenol-A and 17b-oestradiol, on Cerastoderma edule from south-west England: Field study and laboratory exposure. Journal of the Marine Biological Association of the United Kingdom, 97(2), 347-357.

Magalhães, L., Freitas, R., Dairain, A., \& de Montaudouin, X. (2017). Can host density attenuate parasitism? Journal of the Marine Biological Association of the United Kingdom, 97(3), 497-505. https://doi. org/10.1017/S0025315416001107

Magalhães, L., Freitas, R., \& de Montaudouin, X. (2016). Cockle population dynamics: Recruitment predicts adult biomass, not the 
inverse. Marine Biology, 163(16), 1-10. https://doi.org/10.1007/ s00227-015-2809-3

Malham, S. K., Hutchinson, T. H., \& Longshaw, M. (2012). A review of the biology of European cockles (Cerastoderma spp.). Journal of the Marine Biological Association of the United Kingdom, 92(7), 1563-1577.

Marcogliese, D. J. (2001). Implications of climate change for parasitism of animals in the aquatic environment. Canadian Journal of Zoology, 8, 1331-1352. https://doi.org/10.1139/z01-067

Marcogliese, D. J. (2008). The impact of climate change on the parasites and infectious diseases of aquatic animals. Revue Scientifique Et Technique, 27(2), 467-484.

Martínez, L., Freire, R., Arias-Pérez, A., Méndez, J., \& Insua, A. (2015). Patterns of genetic variation across the distribution range of the cockle Cerastoderma edule inferred from microsatellites and mitochondrial DNA. Marine Biology, 162, 1393-1406. https://doi. org/10.1007/s00227-015-2676-y

Martínez-Castro, C., \& Vázquez, E. (2012). Reproductive cycle of the cockle Cerastoderma edule (Linnaeus 1758) in the Ría De Vigo (Galicia, Northwest Spain). Journal of Shellfish Research, 31(3), 757-767.

Morgan, E., O' Riordan, R. M., \& Culloty, S. C. (2013). Climate change impacts on potential recruitment in an ecosystem engineer. Ecology and Evolution, 3(3), 581-594. https://doi.org/10.1002/ece3.419

Morgan, E., O'Riordan, R. M., Kelly, T. C., \& Culloty, S. C. (2012). Influence of disseminated neoplasia, trematode infections and gametogenesis on surfacing and mortality in the cockle Cerastoderma edule. Diseases of Aquatic Organisms, 98, 73-84. https://doi. org/10.3354/dao02428

Navarro, E., Iglesias, J. I. P., \& Larrañaga, A. (1989). Interannual variation in the reproductive cycle and biochemical composition of the cockle Cerastoderma edule from Mundaca Estuary (Biscay, North Spain). Marine Biology, 101, 503-511. https://doi.org/10.1007/ BF00541652

Orton, J. (1926). On the rate of growth of Cardium edule. Part I. Experimental observations. Journal of the Marine Biological Association, 14(2), 239-279. https://doi.org/10.1017/S002531540 0007876

Ponsero, A., Dabouineau, L., \& Allain, J. (2009). Modelling of common European cockle Cerastoderma edule fishing grounds aimed at sustainable management of traditional harvesting. Fisheries Science, 75(4), 839-850. https://doi.org/10.1007/s12562-009-0110-4

R Core Team. (2019). R: A language and environment for statistical computing. R Foundation for Statistical Computing.

Rueda, J. L., Smaal, A. C., \& Scholten, H. (2005). A growth model of the cockle (Cerastoderma edule L.) tested in the Oosterschelde estuary (The Netherlands). Journal of Sea Research, 54, 276-298. https://doi. org/10.1016/j.seares.2005.06.001

Rygg, B. (1970). Studies on Cerastoderma edule (L.) and Cerastoderma glaucum (Poiret). Sarsia, 43, 65-80.

Shaw, B. L., \& Battle, H. I. (1957). The gross and microscopic anatomy of the digestive tract of the oyster Crassostrea virginica (Gmelin). Canadian Journal of Zoology, 35(3), 325-347. https://doi.org/10.1139/ z57-026

The Marine Institute and Bord lascaigh Mhara. (2018). Shellfish Stocks and Fisheries Review 2018. Ireland: The Marine Institute and Bord lascaigh Mhara.
Thieltges, D. W. (2006). Parasite induced summer mortality in the cockle Cerastoderma edule by the trematode Gymnophallus choledochus. Hydrobiologia, 559, 455-461. https://doi.org/10.1007/s1075 0-005-1345-4

Thieltges, D. W., \& Reise, K. (2006). Metazoan parasites in intertidal cockles Cerastoderma edule from the northern Wadden Sea. Journal of Sea Research, 56, 284-293. https://doi.org/10.1016/j. seares.2006.06.002

Thieltges, D. W., \& Reise, K. (2007). Spatial heterogeneity in parasite infections at different spatial scales in an intertidal bivalve. Oecologia, 150, 569-581. https://doi.org/10.1007/s0044 2-006-0557-2

Tully, O., \& Clarke, S. (2016). Review of the Dundalk Bay Cockle Fishery Natura Plan. Ireland: Marine Institute.

Uthicke, S., Schaffelke, B., \& Byrne, M. (2009). A boom-bust phylum? Ecological and evolutionary consequences of density variations in echinoderms. Ecological Monographs, 79(1), 3-24. https://doi. org/10.1890/07-2136.1

van der Meer, J., Beukema, J. J., \& Dekker, R. (2001). Long-term variability in secondary production of an intertidal bivalve population is primarily a matter of recruitment variability. Journal of Animal Ecology, 70, 159-169.

Vaz, N., Dias, J. M., Leitão, P., \& Martins, I. (2005). Horizontal patterns of water temperature and salinity in an estuarine tidal channel: Ria de Aveiro. Ocean Dynamics, 55, 416-429. https://doi.org/10.1007/ s10236-005-0015-4

Wegeberg, A. M., \& Jensen, K. T. (1999). Reduced survivorship of Himasthla (Trematoda, Digenea)-infected cockles (Cerastoderma edule) exposed to oxygen depletion. Journal of Sea Research, 42, 325331. https://doi.org/10.1016/S1385-1101(99)00035-0

Welsh, J. E., Liddell, C., van der Meer, J., \& Thieltges, D. W. (2017). Parasites as prey: The effect of cercarial density and alternative prey on consumption of cercariae by four non-host species. Parasitology, 144(13), 1775-1782. https://doi.org/10.1017/S0031182017001056

Yankson, K. (1986). Reproductive cycles of Cerastoderma glaucum (Bruguière) and C. edule (L.) with special reference to the effects of the 1981-82 severe winter. Journal of Molluscan Studies, 52, 6-14. https://doi.org/10.1093/mollus/52.1.6

You, W., \& Hedgecock, D. (2019). Boom-and-bust production cycles in animal seafood aquaculture. Reviews in Aquaculture, 11, 1045-1060. https://doi.org/10.1111/raq.12278

\section{SUPPORTING INFORMATION}

Additional supporting information may be found online in the Supporting Information section.

How to cite this article: Mahony KE, Lynch SA, Egerton S, et al. Latitudinal influence on gametogenesis and hostparasite ecology in a marine bivalve model. Ecol Evol. 2021;11:7029-7041. https://doi.org/10.1002/ece3.7551 